\title{
INTEGRALITY IN HEALTH CARE FOR THE ELDERLY: A PUBLIC HEALTH ISSUE
}

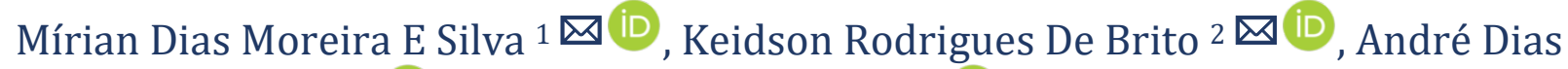

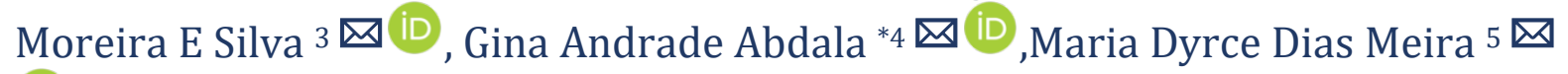
iD

${ }^{* 1}$ Northern Military Command Medical, Brazil

2 IASD Paulistana Association, Brazil

${ }^{3}$ Military Hospital of São Paulo Area, Brazil

4,5 Adventist University os São Paulo, Brazil

DOI: https://doi.org/10.29121/granthaalayah.v8.i11.2020.2470

Article Type: Research Article

Article Citation: Gina Andrade Abdala, Mírian Dias Moreira E Silva, Keidson Rodrigues De Brito, André Dias Moreira E Silva, and Maria Dyrce Dias Meira. (2020). INTEGRALITY IN HEALTH CARE FOR THE ELDERLY: A PUBLIC HEALTH ISSUE. International Journal of Research GRANTHAALAYAH, 8(11), 311-317. https://doi.org/10.29121/granthaa layah.v8.i11.2020.2470

Received Date: 15 November 2020

Accepted Date: 30 November 2020

Keywords:

Comprehensive Health Care

Health of the Elderly

Public Health Policy

Health Promotion

\section{ABSTRACT}

Introduction: the demands for goods and services aimed at the health needs of the elderly require a different perspective that considers the human being in all its dimensions: biopsychosocial and spiritual. Objective: to reflect on the assistance strategies that impact comprehensive care for the elderly, based on public health policies.

Methodology: reflective essay that contextualizes comprehensive care for the elderly.

Results: the content is presented in four sections: "Population aging in Brazil" "Public Health Policies: a brief historical recovery"; "Comprehensiveness in health care: practices and challenges" and, finally, "Training to work in the health of the elderly and communication strategies".

Conclusion: it is clear that different care strategies, including verbal and non-verbal communication, contribute to greater comprehensiveness and humanization in the care of the elderly. It also appears that public health policies depend on intersectoral integration to provide care for the elderly in a holistic way.

\section{INTRODUCTION}

The demographic pattern of the Brazilian population has been configured in a context of significant structural changes since the 1960s, which have led to an inversion of the population pyramid whose repercussions are differentiated in the various social and political instances. As a result of this context, it is necessary to look at the needs of the elderly with regard to new demands for goods and services, as well as on the lifestyle and health care of this population. [1] 
Population aging is a reality in many countries, including Brazil, whose number of individuals over the age of 60 has grown tremendously in recent decades. Brazil currently has approximately 26 million people over the age of 60 . [1], [2] Estimates indicate that this age group could reach around 73.5 million people in up to 50 years, more than triple the current number, being that this fact calls the attention and already represents a challenge for the health systems. [3], [4]

It appears that the increase in the elderly population has occurred, in parallel, to a substantial increase in the occurrence of Chronic Noncommunicable Diseases (CNCD) and diseases that figure as the main causes of illness and death. [5] In addition, the current Brazilian situation was not enough, with a serious economic and political crisis, can worsen the health situation of the elderly even more by making social protection of a population considered vulnerable and that demands more and more attention, especially in the health sector. [4]

In this context, the importance of the issues surrounding the management of self-care and the longitudinality of care in multi professional and intersectoral actions is reinforced, including aspects related to the spiritual dimension of the elderly. In this sense, studies have shown evidence that the greater the spiritual involvement of the elderly person, the better their quality of life. [6], [7] It is recognized that despite the centrality and relevance of this theme there is an inherent complexity in addressing it in the context health of the elderly.

From a comprehensive perspective, there is a range of individual, existential and social factors that are determinants of the health conditions of the elderly. The present text, far from seeking a definitive pronouncement on the subject, seeks to integrate itself into the debate in the field of public health, as a refractory space and source of notes. Thus, the objective of this essay was to reflect on the assistance strategies that impact the comprehensive care of the elderly, based on public health policies.

\section{METHOD}

It is a reflective essay that contextualizes the integrality of assistance to the elderly. To this end, a brief narrative review on the topic of comprehensiveness and its relationship with care strategies that interfere with the treatment and well-being of the elderly was adopted as a substrate, with the public policies established as an outline.

\section{RESULTS}

The theme is addressed in four topics that briefly contextualizes and rescues public health policies and their implications for health professionals' practices, as well as the role of effective communication to promote comprehensive care for the elderly.

\section{POPULATION AGING IN BRAZIL}

Globally, population aging is recognized as one of the main social achievements of the 20th century, however, it poses major challenges for Public Health Policies in the world. In developed countries, this phenomenon occurred at a favorable social and economic moment, which allowed the expansion of their social protection systems. In developing countries and, specifically, in the Brazilian case, accelerated aging is occurring amid a recessive conjecture of political and economic crisis, which makes it difficult to expand the social protection system for all age groups and, in particular, for the elderly. [8]

It is worth remembering the proposals of the "Regional strategy for the implementation of the international Madrid Action Plan for aging in Latin America", approved in 2003, at the first Intergovernmental Regional Conference on Aging in Latin America and the Caribbean. On that occasion, goals were proposed in three areas considered as priorities: "elderly people and development; fostering health and well-being in old age and creating an environment that is conducive and favorable to the needs and demands of this social segment" (free translation). [9]

In addition, it is worth noting that the change that occurred after the promulgation of the 1988 Brazilian Constitution, which advocates health as the right of all and the duty of the State, is notable. [10] Despite the implications of this guarantee, it is considered that there was an advance towards public health with regard to minimum assistance rights, which legitimizes the right of the elderly person, then becoming the object of public policies with recognition of their social role. [11] 
Linked to this, it is understood that the comprehensiveness conceived within the scope of the Unified Health System (SUS) goes far beyond a guideline, as it represents the transformation of the traditional health model prevalent in Brazil. SUS brings in its scope the principle of integrality in health, which, among other factors, comes up against the need for interdisciplinary training for the effectiveness of comprehensive care for the individual. This is pointed out as a fundamental condition for interprofessional relationships to be established in the services and to be incorporated between the different levels of care, as well as in the interrelationships necessary for teamwork. [12]

\section{PUBLIC HEALTH POLICIES: A BRIEF HISTORICAL RECOVERY}

From a historical point of view, successive initiatives related to the elderly are worth mentioning in the field of public health policies. The Family Health Strategy (FHS) was instituted in 1994 by the Ministry of Health with the aim of reversing the current care model by creating a more appropriate approach for people assisted in Primary Health Care (PHC). Community care for the elderly, at this level of care, should be based especially on the family structure. [13], [14] In order to improve the quality of life of the elderly, several laws and decrees have been published, including the National Policy for the Elderly, Law No. 8,842, of January 4, 1994, regulated by Decree Law No. 1,948, of July 3,1996, which guarantees priorities in meeting these. [15]

Another aspect that stands out was the creation of the National Elderly Health Policy approved through Ordinance No. 1,395, of December 10,1999, whose essential objective was to ensure the social rights of the elderly, creating conditions to promote their autonomy, integration and effective participation in society. [16] This Policy was expanded through Ordinance № 2,528 in 2006, incorporating actions aimed at guaranteeing the rights of the elderly in different sectors of society. [17]

Thus, despite the advances and the consolidation of Public Health Policies, especially linked to PHC, the guarantee of comprehensive care in the elderly remains a major challenge. In this matter, it is necessary to consider the paradigm of functionality in home care and in the training of professionals prepared to foster this debate in the context of public health. [18]

Through the aforementioned policies, it is noted that, from a legal point of view, measures and forms of action aimed at improving care for the elderly have been created, with emphasis on the way such care is offered. A differentiated attention is increasingly perceived, with notable health and social security impacts caused by the aging of the population.

\section{COMPREHENSIVENESS IN HEALTH CARE: PRACTICES AND CHALLENGES}

In the context of PHC, in addition to diagnosing and treating diseases, the multidisciplinary team involved in the organization of health care for the elderly should offer care that additionally includes health promotion through preventive and curative actions articulated, in order to guarantee comprehensiveness. The search for comprehensiveness has become a priority issue for PHC, however it has been difficult to operationalize it in practical propositions, especially because the biomedical culture, centered on drug treatment and with an emphasis on meeting production goals, still prevails at this level of attention. This occurs to the extent that the disease and its consequences are focused on, and not the individual in all its dimensions. [19], [20]

The conditions that interfere with the well-being of senescence and the factors associated with the quality of life of the elderly have been worked on in "Health Promotion Groups" aimed at welcoming and accompanying the elderly person. This initiative proposes the creation of alternative interventions that promote actions in the health area, to meet the demands of the aging population and the aspects of quality of life that should be prioritized in PHC. [21]

To improve the quality of life of the elderly, it is necessary to renew the practices of care in health care networks, promoting self-care and autonomy of the elderly and, at the same time, expanding their horizons of possibilities. In this sense, there is a study that evaluated practitioners and non-practitioners of physical activities, about how they experienced their identity as elderly, from the category "third age". The authors refer that there was a predominance of speeches that highlighted the positive aspects of an active and healthy aging that, coupled with the practice of 
Integrality in Health Care for The Elderly: A Public Health Issue

physical exercises, implies greater dynamism and better quality of life. By reaffirming the identity built on health ideals, disseminated by the media, they reinforced values such as individualism and self-responsibility. [22]

In the context of health promotion, comprehensiveness is presented in two dimensions: in the perspective of articulation between preventive and curative actions and in the holistic view of the human being, who occupies a prominent place in the provision of health care. It includes in its operationalization practical propositions, focused on the care process, whose conduction must be performed and reassessed within the scope of SUS, especially by the PHC, which serves as the system's preferential gateway. [23], [24]

From this panorama, it follows that the scope of comprehensiveness encompasses an attempt to approach and understand more deeply the various dimensions of the elderly's life, which transcends the mere prescription of medicines, projecting an investigation of causes and effects along with a proposition of paths and reflections.

\section{TRAINING TO WORK IN THE HEALTH OF THE ELDERLY AND COMMUNICATION STRATEGIES}

Among the challenges to putting integrality into practice is, above all, the biomedical culture centered on drug treatment. This is because in this model, human beings are not taken into account in all their dimensions, but care focused on symptoms and specialties. [19], [20]

It is important to note the need for investment in the training and involvement of health professionals in the planning and implementation of health promotion activities in a comprehensive perspective. It is recommended that, in this sense, multidisciplinary aspects should be considered in the development of skills to deal with the complexity of issues that encompass comprehensive care for the elderly, as well as the encouragement and commitment of the various sectors involved. Permanent health education, instituted through Ordinance №. 198 / GM proposes significant learning in the context of work in which "learning and teaching are incorporated into the daily life of organizations and work", based on health needs prevalent for the improvement of professional practices. [25]

For transformations in professional practices to occur, critical reflection must be promoted, based on the problematization of reality, in which training needs are identified. Thus, the proposed actions may contribute so that health professionals and users understand and act in the complexity of care, aiming at integrality and humanization in services. [26] Political, social and sanitary achievements must be valued in prevention and health promotion activities in order to contribute to improving the quality of life of the elderly, in the context of the community where they live.

Health promotion aims to optimize the standard of living and health, prioritizing the identification and coping with the social determinants that generate the illness process, as well as, valuing the interaction process that can enhance group actions. [21] Thus, it is up to the health professionals, especially to the doctor, not only the prescription of medicines or care, but also the application of strategies that help in the prevention of pathologies, always with a "humanizing" and empathic look.

In this direction, Lima et al. (2018) [27] recommend that, specifically in the case of the elderly assisted in PHC, it is necessary to take into account that many have low education and / or signs of senility. Therefore, for a service with a view to comprehensiveness, it is assumed that effective communication becomes a precious work tool to alleviate such difficulties. According to Moraes (2012, p. 34) [28], "communicative skills comprise four distinct areas: language, hearing, oral motor skills and speech / voice". The author further argues that the vision has a compensatory communicative function that can be included in the absence of other skills of the elderly person.

The correct use of verbal and non-verbal language increases the possibilities of the elderly to feel welcomed when entering health units. A good rate of speech and frequent eye contact help to establish a connection between professional and patient, as the patient sees himself respected in his information processing time. In addition, facial expressions help to better understand and express empathy, which is extremely important for the elderly to feel encouraged to proceed with the treatment. [29] Such strategies promote the construction of a respectful and empathic relationship, in which an emotional connection and the necessary stimulus for the adoption of prevention and health promotion practices are created, mainly for the realization of the proposed therapeutic plan.

\section{FINAL CONSIDERATIONS}

In view of the purpose of improving the quality of life of the elderly, the conclusion reached is that the health promotion policy appears as a strategy of the health movement to improve the health of Brazilians. In this sense, 
comprehensive health care is seen as a desirable feature for the effectiveness of the health system and its practices. Regarding health policies, they are considered to have the purpose of promoting healthy aging; maintaining and improving the functional capacity of the elderly; disease prevention; the recovery of health and the rehabilitation of those who will have their basic functions restricted. These actions must be carried out in such a way as to ensure that they remain in the environment in which they live, independently exercising their functions in society.

It should also be noted that verbal and non-verbal communication strategies are effective in the sense of acting as "humanizing elements" between health professionals and patients. Visual contacts, accessible and paused language, compatible with the condition of the elderly, are highly effective attitudinal skills in creating stimuli for the reception of the patient, which are concretized in the relationship of reciprocity with health professionals.

When reflecting on this theme, it is observed that there have been advances on the part of the State in creating laws and instituting policies for the implementation of comprehensive care for the elderly. It is also noticed that there is an increase in the interest of educational institutions, public and private, to promote the training of professionals who have a focus on humanized care, considering the integrality of the human being. The gap that is observed is that the demand for the needs of the population is greater than the efforts made by the State in all areas with a view to promoting comprehensive care for the elderly. In this sense, comprehensive care for the elderly is present as the focus is not restricted only to the treatment of illnesses, but in a whole set of multidisciplinary practices aimed at the well-being of the patient, physically, emotionally and spiritually.

\section{SOURCES OF FUNDING}

This research received no specific grant from any funding agency in the public, commercial, or not-for-profit sectors.

\section{CONFLICT OF INTEREST}

The author have declared that no competing interests exist.

\section{ACKNOWLEDGMENT}

None.

\section{REFERENCES}

[1] Simões CCS. Relações entre as alterações históricas na dinâmica demográfica brasileira e os impactos decorrentes do processo de envelhecimento da população. Rio de Janeiro: IBGE, Coordenação de População e Indicadores Sociais, 2016. p. 98-119. [Access in: 28 mai. 2018] Available in: $<$ https://biblioteca.ibge.gov.br/visualizacao/livros/liv98579.pdf>.

[2] Ministério do Planejamento, Desenvolvimento e Gestão (Brasil). Instituto Brasileiro de Geografia Estatística IBGE. Síntese de indicadores Sociais, 2015. [Access: 28 mai. 2018] Available in: <https://www.ibge.gov.br/estatisticas-novoportal/sociais/populacao/9221-sintese-de-indicadoressociais.html?=\&t=downloads $>$.

[3] Borges GM, Campos MB, Silva LGC. Transição da estrutura etária no Brasil: oportunidades e desafios para as próximas décadas. In: Ervatti LR, Borges GM, Jardim AP (Org.). Mudança demográfica no Brasil no início do século XXI: Subsídios para as projeções das populações. Brasília, DF: IBGE, 2015.

[4] Miranda GMD, Mendes ACG, Silva ALA. Envelhecimento da população no Brasil: desafios e consequências sociais atuais e futuros. Rev. Bras. Geriatr. Gerontol., Rio de Janeiro, v. 19, n. 3, p. 507-519, 2016. [Access: 16 ago. 2017] Available in: <http://www.scielo.br/pdf/rbgg/v19n3/1809-9823-rbgg-19-03-00507.pdf>.

[5] Dantas IC, Pinto Junior EP, Medeiros KKAS, Souza EA. Perfil de morbimortalidade e os desafios para a atenção domiciliar do idoso brasileiro. RevistaKairósGerontol. 2017 jan./mar; 20(1):93-108. [Access: 16 ago. 2017] Available in: <https://revistas.pucsp.br/index.php/kairos/article/view/2176-901X.2017v20i1p93108/22192>. 
Integrality in Health Care for The Elderly: A Public Health Issue

[6] Santos NC, Abdala GA. Religiosidade e Qualidade de vida relacionada à saúde dos idosos em um município da Bahia, Brasil. Rev. Bras. Geriatr. Gerontol., 2014 dez; 17(4):795-805.

[7] Abdala GA, Kimura M, Duarte YAO, Lebrão ML, Santos B. Religiosidade e Qualidade de Vida Relacionada à Saúde do idoso. Rev Saúde Pública, 2015 set; 49:55. [Citado em: 20 ago. 2017] Available in:: <http://dx.doi.org/10.1590/S0034-8910.201504900541>.

[8] Mendonça JMB. Políticas Públicas Para Idosos no Brasil: Análise à luz da influência das Normativas Internacionais [tese]. Brasília: Departamento de Serviço Social, Universidade de Brasília; 2015. $172 f$.

[9] Huenchuan S. (ed). Envejecimiento, derechos humanos y políticas públicas. Santiago de Chile: Comisión Económica para América Latina y el Caribe (CEPAL); abril, 2009.

[10] Brasil. Constituição (1988) Constituição da República Federativa do Brasil. 1988 Brasilia: Senado Federal; 1988. 292p.

[11] Silva MRF, Yazbek MC. Proteção social aos idosos: concepções, diretrizes e reconhecimento de direitos na América Latina e no Brasil, R. Katál. 2014 jan./jun;17(1):102-10.

[12] Pinheiro R. As práticas do cotidiano na relação oferta e demanda dos serviços de saúde: um campo de estudo e construção da integralidade. In: Pinheiro R, Matos RA (org.). Os sentidos da integralidade no cuidado à saúde. Rio de Janeiro: UERJ, IMS: ABRASC0, 8ª . edição. 2009.p. 69-116.

[13] Ministério da Saúde (Brasil). Secretaria de Atenção à Saúde. Departamento de Atenção Básica. Política Nacional de Atenção Básica (PNAB). Brasília: Ministério da Saúde, 2012. (Série E. Legislação em Saúde).

[14] Fertonani HP, Pires DEP, Biff D, Scherer MDA. O modelo assistencial: conceitos e desafios para a atenção básica em saúde no Brasil. Ciênc. saúde coletiva [Internet]. 2015 jun. 20(6):1869-78, jun. 2015. http://dx.doi.org/10.1590/1413-81232015206.13272014

[15] Brasil. Decreto no 1.948, de 03 de Julho de 1996. Regulamenta a Lei no 8.842, de janeiro de 1994, que dispõe sobre a Política Nacional do Idoso, e dá outras providências. Diário Oficial da República Federativa do Brasil. Brasília, DF, 4 jul. 1996.

[16] Ministério da Saúde (Brasil). Portaria no 1.395, de 10 de dezembro de 1999. In: Brasil. Política Nacional de Saúde do Idoso. Brasília, 1999. [Access: 16 ago. 2017]. Available in: <http://dtr2004.saude.gov.br/susdeaz/legislacao/arquivo/Portaria_1395_de_10_12_1999.pdf>.

[17] Ministério da Saúde (Brasil). Portaria no 2.528, de 19 de outubro de 2006. Aprova a Política Nacional de Saúde da Pessoa Idosa. In: BRASIL. Política Nacional de Saúde da Pessoa Idosa. 2006. Available in: <http://portal.saude.gov.br/portal/arquivos/pdf/2528_pnspi.pdf>. Access: 24 abr. 2018.

[18] Arantes LJ, Shimizu HE, Merchán-Hamann E. Contribuições e desafios da Estratégia Saúde da Família na Atenção Primária à Saúde no Brasil: revisão da literatura. Ciênc. saúde coletiva, [Internet] 2016 mai; 21(5):1499-509. [Access: 2 out. 2017] Available in: <http://dx.doi.org/10.1590/141381232015215.19602015>.Acesso em: 2 mai. 2018.

[19] Martins AB, D’Avila OP, Hilgert JB, Hugo FN. Atenção Primária a Saúde voltada as necessidades dos idosos: da teoria à prática. Ciênc. saúdecoletiva[Internet]. 2014 ago; 19(8):3403-16. [Access: 25 jul. 2018] Available in: <http://dx.doi.org/10.1590/1413-81232014198.13312013>.

[20] Campos RTO, Ferrer AL, Gama CAP, Campos GWS, Trapé TL, Dantas DV. Avaliação da qualidade do acesso na atenção primária de uma grande cidade brasileira na perspectiva dos usuários. Saúde debate [Internet]. 2014 out; 38(esp):252-64. [Access: 16 ago. 2017] Available in: <http://dx.doi.org/10.5935/01031104.2014S019>.

[21] Paula GR, Souza BN, Santos LF, Barbosa MA, Brasil VV, Oliveira LMAC. Qualidade de vida para avaliação de grupos de promoção da saúde. Rev. Bras. Enferm. [Internet].2016 abr; 69(2):242-9. [Access: 16 abr. 2018] Available in: <http://dx.doi.org/10.1590/0034-7167.2016690206i>.

[22] Velôso TMG, Oliveira Filho P, Henriques HDB, Henriques HIB, Meira MC. Descrições sobre a velhice: a identidade terceira idade em depoimentos de idosos. Estud. Interdiscipl. Envelhec. $2017 \mathrm{dez}$; 22(30:79-97.

[23] Aquino R, Medina MG, Nunes CA, Souza MF. Estratégia de Saúde da Família e reordenamento do sistema de serviços de saúde. In: Paim JS, Almeida-Filho N (Org.). Saúde Coletiva: teoria e prática. Rio de Janeiro: Medbook, 2014. p. 353-71.

[24] Pellegrini Filho A, Buss PM, Esperidião MA. Promoção da Saúde e seus fundamentos: determinantes sociais da saúde, ação intersetorial e políticas saudáveis. In: Paim JS, Almeida-Filho N (Org.). Saúde coletiva: teoria e prática. Rio de Janeiro: Medbook, 2014. p. 305-26. 
[25] Ministério da Saúde (Brasil). Portaria n.198/GM, de 13 de fevereiro de 2004. Politica Nacional de Educação Permanente em Saúde como estratégia do Sistema Único de Saúde para a formação e o desenvolvimento de trabalhadores para o setor e dá outras providências. In: Brasil. Politica Nacional de Educação Permanente em Saúde. Brasília, 2004. p. 49.

[26] Carnut L. Cuidado, integralidade e atenção primária: articulação essencial para refletir sobre o setor saúde no Brasil. Saúde debate [Internet]. 2017 dez; 41(115):1177-86. [Access: 16 ago. 2018] Available in:<http://dx.doi.org/10.1590/0103-1104201711515>.

[27] Lima BC, Fonseca BR, Schoeler GM, Lobo HLV, Mello D, Vitarelli AMA. importância da comunicação e o cuidado com o paciente visando o letramento funcional em saúde: uma revisão bibliográfica. Rev Interdisc. Pensamento Cient., 2018; 1(4):82-89. http://dx.doi.org/10.20951/2446-6778/v4n1a10.

[28] Moraes ENM. Atenção à saúde do Idoso: Aspectos Conceituais. Brasília: Organização Pan-Americana da Saúde, 2012; $98 \mathrm{p}$.

[29] Torres GMC, Figueiredo IDT, Cândido JAB, Pinto AGA. Comunicação não-verbal no cuidado com usuários hipertensos na Estratégia Saúde da Família. REFACS [Internet]. 2019; 7(3):284-295. http://dx.doi.org/10.18554/refacs.v7i3.3570. 